\title{
KINERJA SEKTOR PERTANIAN DAN NON PERTANIAN DALAM PEREKONOMIAN WILAYAH DI PROPINSI MALUKU UTARA
}

\author{
Yonette Maya Tupamahu \\ Staf Pengajar FAPERTA UMMU-Ternate, e-mail: ymtup@yahoo.co.id
}

\begin{abstract}
ABSTRAK
Penelitian ini bertujuan untuk menganalisis kinerja sektor pertanian dan non pertanian, menganalisis kinerja sektor pertanian dan non pertanian pada masa mendatang, dan melakukan klasifikasi sektor perekonomian di Propinsi Maluku Utara. Metode analisis yang digunakan adalah $L Q, D L Q$, dan klasifikasi sektor usaha berdasarkan nilai LQ dan DLQ. Hasil analisis LQ menunjukkan bahwa sektor pertanian, pertanian tanaman pangan, perkebunan, kehutanan dan perikanan termasuk sektor basis di Propinsi Maluku Utara, sedangkan peternakan termasuk sektor non basis. Sektor basis non pertanian yaitu perdagangan, hotel dan restoran. Analisis DLQ menunjukkan dimasa mendatang sektor pertanian, pertanian tanaman pangan, perkebunan, peternakan, dan perikanan mengalami peningkatan kinerja. Sektor non pertanian pun menunjukkan peningkatan kinerja sehingga menjadi sektor basis dimasa mendatang, yaitu sektor pertambangan dan penggalian, industri pengolahan, listrik, gas dan air bersih, perdagangan, hotel dan restoran, pengangkutan dan komunikasi, keuangan, persewaan dan jasa, dan sektor jasa-jasa. Klasifikasi sektor di Propinsi Maluku Utara berdasarkan nilai LQ dan DLQ yaitu: (a) Sektor unggulan: sektor pertanian, pertanian tanaman pangan, perkebunan, dan perikanan; serta sektor perdagangan, hotel dan restoran. (b) Sektor andalan: peternakan, sektor pertambangan dan penggalian, industri pengolahan, listrik, gas dan air bersih, pengangkutan dan komunikasi, keuangan, persewaan dan jasa, serta sektor jasa-jasa. (c) Sektor prospektif: kehutanan, dan (d) Sektor tertinggal: bangunan.
\end{abstract}

Kata Kunci: sektor basis, sektor non basis, analisis $L Q$, analisis $D L Q$

\section{PENDAHULUAN}

1.1. Latar Belakang

Propinsi Maluku Utara merupakan salah satu propinsi di Indonesia dengan karakteristik kepulauan. Pembangunan di sektor ekonomi digalakkan dalam upaya meningkatkan kesejahteraan masyarakat kepulauan atau pulau-pulau kecil. Pemerintah daerah dan masyarakat bersama-sama mengelola sumberdaya di daerah dalam suatu kemitraan, agar dapat menciptakan suatu lapangan usaha baru dan merangsang perkembangan ekonomi di wilayah tersebut.

Untuk menjamin potensi unggulan daerah dapat berkembang sesuai dengan tujuan pembangunan daerah, maka setiap pemerintah daerah senantiasa berupaya memberikan perhatian dan fasilitasi yang memadai sesuai dengan kemampuan daerah masing-masing. Pengembangan potensi unggulan daerah yang dilakukan secara terpadu dan berkelanjutan sesuai dengan rencana pembangunan daerah diharapkan dapat meningkatkan produktivitas ekonomi daerah (Rustiadi, dkk., 2009 dalam Santoso, dkk., 2012).

Perbedaan tingkat pembangunan yang di dasarkan atas potensi suatu daerah, berdampak terjadinya perbedaan sektoral dalam pembentukan Produk Domestik Regional Bruto (PDRB). Data PDRB merupakan informasi ukuran kinerja makro kegiatan ekonomi di suatu wilayah tertentu 
(propinsi/kabupaten/kota) menggambarkan struktur ekonomi daerah, peranan sektor-sektor ekonomi dan pergeserannya, serta menunjukkan laju pertumbuhan ekonomi, baik secara total maupun per sektor.

PDRB Maluku Utara atas dasar harga berlaku pada tahun 2013 sebesar $6.918 .361,1$ juta rupiah atau $34,91 \%$ untuk sektor pertanian, disusul sektor perdagangan, hotel dan restoran dengan sumbangan sebesar $25,57 \%$. Sektor industri pengolahan diharapkan mampu menunjang sektor pertanian dengan berorientasi pada agriindustri pada tahun 2012 memberikan sumbangan sebesar 12,59\%. PDRB Maluku Utara atas dasar harga konstan pada tahun 2012 sebesar 3.445.480,4 juta rupiah atau meningkat sebesar 4,22\% dari tahun 2011.

Data tersebut menunjukkan pertanian merupakan sektor dengan penyumbang PDRB tertinggi dibanding sektor lainnya di Propinsi Maluku Utara. Sektor ini menjadi basis mata pencaharian masyarakat terutama di pedesaan. Berdasarkan angka sementara hasil pencacahan lengkap Sensus Pertanian 2013, jumlah usaha pertanian di Maluku Utara sebanyak 130.183 dikelola oleh rumah tangga, sebanyak 38 dikelola oleh perusahaan pertanian berbadan hukum, dan sebanyak 53 dikelola oleh selain rumah tangga dan perusahaan berbadan hukum. Pemilihan sektor pertanian sebagai basis pembangunan kawasan perlu dilakukan dengan mempertimbangkan sumber daya yang ada, multiplier effect, maupun kesesuaian dengan kondisi ekonomi masyarakat (BPS Maluku Utara, 2013).

Adanya data PDRB maka dapatlah ditentukan dengan jelas apakah suatu sektor tergolong dalam sektor basis atau sektor non basis. Sektor basis adalah sektor yang menjadi tulang punggung perekonomian daerah karena mempunyai keuntungan kompetitif (Competitive Advantage) yang cukup tinggi (Sjafrizal, 2008). Setiap perubahan yang terjadi pada sektor basis akan menimbulkan efek ganda (multiplier effect) dalam perekonomian regional (Adisasmita, 2005). Sedangkan sektor non basis adalah sektor-sektor lainnya yang kurang potensial tetapi berfungsi sebagai penunjang sektor basis atau service industries (Sjafrizal, 2008).
Selain itu dengan bantuan data PDRB, maka dapat ditentukannya sektor unggulan (leading sector) di suatu daerah/wilayah. Sektor unggulan adalah satu grup sektor/subsektor yang mampu mendorong kegiatan ekonomi dan menciptakan kesejahteraan di suatu daerah terutama melalui produksi, ekspor dan penciptaan lapangan pekerjaan, sehingga identifikasi sektor unggulan sangat penting terutama dalam rangka menentukan prioritas dan perencanaan pembangunan ekonomi di daerah.

\subsection{Tujuan Penelitian}

Penelitian ini bertujuan untuk :

1. Menganalisis kinerja sektor pertanian dan non pertanian di Propinsi Maluku Utara.

2. Menganalisis kinerja sektor pertanian dan non pertanian pada masa mendatang di Propinsi Maluku Utara.

3. Melakukan klasifikasi sektor perekonomian di Propinsi Maluku Utara.

\section{METODE PENELITIAN}

\subsection{Metode Penentuan Lokasi}

Lokasi penelitian adalah Propinsi Maluku Utara, penentuan lokasi ini dilakukan secara sengaja (purposive). Pertimbangan penelitian dilakukan di Propinsi Maluku Utara adalah agar hasil penelitian ini berupa sektorsektor unggulan perekonomian dapat digunakan sebagai informasi dan dapat diprioritaskan dalam perencanaan pembangunan Propinsi Maluku Utara.

\subsection{Jenis dan Sumber Data}

Jenis data yang dibutuhkan dalam penelitian ini adalah data sekunder yang bersumber dari Badan Pusat Statistik Propinsi Maluku Utara dan Badan Pusat Statistik RI. Data yang diambil yaitu: Produk Domestik Bruto Regional (PDRB) dan Laju PDRB atas Dasar Harga Konstan 2000 menurut Lapangan Usaha Propinsi Maluku Utara dan Produk Domestik Bruto (PDB) Indonesia dan Laju PDB Indonesia menurut Lapangan Usaha atas Harga Konstan 2000 periode tahun 2008-2012. Sektorsektor perekonomian berdasarkan lapangan usaha yaitu:
a. Pertanian.
b. Pertambangan dan Penggalian. 


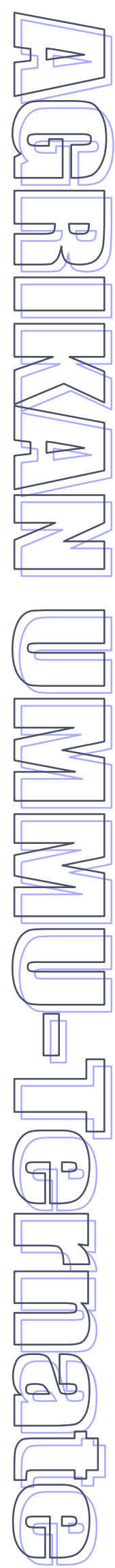

c. Industri Pengolahan.

d. Listrik, Gas dan Air Bersih.

e. Bangunan/Konstruksi.

f. Perdagangan, Hotel dan Restoran.

g. Pengangkutan dan Komunikasi.

h. Keuangan, Persewaan dan Jasa Perusahaan.

i. Jasa-jasa.

Data series yang digunakan 5 tahun untuk menghindarkan bias musiman dan tahunan. Penggunaan data PDRB dan PDB dengan harga konstan dan dengan tahun dasar yang sama, juga akan dapat memberikan bobot (nilai riilnya) yang sama dan perbandingan akan menjadi valid (Hendayana, 2003).

\subsection{Metode Analisis}

Untuk menjawab tujuan penelitian pertama dan kedua, digunakan analisis Location Quotient. Metode ini dibedakan menjadi dua, yaitu: Static Location Quotient (SLQ sering disebut LQ) dan Dynamic Location Quotient (DLQ). Untuk menjawab tujuan penelitian ketiga digunakan klasifikasi sektor usaha berdasarkan nilai SLQ dan DLQ. Asumsi utama dalam analisis ini adalah bahwa semua penduduk di setiap daerah mempunyai pola permintaan yang sama dengan pola permintaan pada tingkat daerah refrensi (pola pengeluaran secara geografis adalah sama), produktivitas tenaga kerja adalah sama dan setiap industri menghasilkan barang yang sama (homogen) pada setiap sektor (Arsyad, 1999).

\subsubsection{Static Location Quotient (SLQ)}

Metode ini merupakan metode sederhana yang mampu menunjukkan kemampuan ekspor sektor tertentu di suatu daerah terhadap daerah yang lebih besar (Setiono, 2011). Logika dasar LQ adalah teori basis ekonomi yang intinya adalah karena industri basis menghasilkan barang-barang dan jasa untuk pasar di daerah maupun di luar daerah yang bersangkutan, maka penjualan di luar daerah akan menghasilkan pendapatan bagi daerah tersebut (Widodo, 2006). Dikatakan lebih lanjut bahwa adanya arus pendapatan dari luar daerah ini menyebabkan terjadinya kenaikan konsumsi dan investasi di daerah tersebut. Hal ini akan menaikkan permintaan terhadap industri basis, tetapi juga menaikkan permintaan akan industri non basis (lokal).
Kenaikan permintaan ini akan mendorong kenaikan investasi pada industri yang bersangkutan dan juga industri lainnya. Sehingga keberadaan sektor basis tidak terlepas dari pengaruh sektor non basis dan sebaliknya, sektor basis dapat mempengaruhi sektor non basis.

Metode Location Quotient (LQ) dilakukan dengan membandingkan antara pangsa relatif pendapatan sektor i pada tingkat wilayah terhadap pendapatan total wilayah dengan pangsa relatif pendapatan sektor i pada tingkat nasional terhadap pendapatan total nasional. Rumusan SLQ adalah sebagai berikut :

$$
S L Q_{i t}=\frac{v_{i} / v_{t}}{V_{i} / V_{t}}
$$

Keterangan :

$\mathrm{SLQ}_{\mathrm{it}}=$ Indeks Static Location Quotient

$\mathrm{vi}_{\mathrm{i}} \quad=$ Produk Domestik Regional Bruto (PDRB) sektor i Propinsi Maluku Utara

$\mathrm{v}_{\mathrm{t}} \quad=$ Produk Domestik Regional Bruto (PDRB) total sektor i Propinsi Maluku Utara

$\mathrm{V}_{\mathrm{i}}=$ Produk Domestik Bruto (PDB) sektor i Indonesia

$\mathrm{V}_{\mathrm{t}} \quad=$ Produk Domestik Bruto (PDB) total sektor i Indonesia

Apabila nilai LQ > 1, maka suatu sektor perekonomian merupakan sektor basis. Sedangkan bila nilai $L Q<1$, berarti sektor tersebut merupakan sektor non basis (Budiharsono, 2005).

\subsubsection{Dynamic Location Quotient (DLQ).}

Metode DLQ atau LQ dinamis digunakan untuk mengakomodasi perubahan struktur ekonomi wilayah dalam kurun waktu tertentu. Menurut Saharuddin (2006) secara umum metode LQ dinamis mempunyai kesamaan dengan metode LQ statis, hanya yang membedakan model LQ dinamis memasukkan laju pertumbuhan rata-rata terhadap masingmasing nilai tambah sektoral maupun PDRB untuk kurun waktu antara tahun 0 sampai tahun $\mathbf{t}$.

$$
D L Q_{i j}=\left[\begin{array}{l}
\left(1+g_{i j}\right) /\left(1+g_{j}\right) \\
\left(1+G_{i}\right) /(1+G)
\end{array}\right]^{t}
$$


Keterangan :

$$
\begin{aligned}
\text { DLQ }_{\mathrm{ij}}= & \text { Indeks potensi sektor usaha Propinsi } \\
& \text { Maluku Utara } \\
\mathrm{g}_{\mathrm{ij}}= & \text { Laju pertumbuhan PDRB sektor usaha } \\
& \text { Propinsi Maluku Utara } \\
\mathrm{g}_{\mathrm{j}}= & \text { Rata-rata laju pertumbuhan PDRB } \\
& \text { sektor usaha Propinsi Maluku Utara } \\
\mathrm{Gi}= & \text { Laju pertumbuhan PDB sektor usaha } \\
& \text { Indonesia } \\
\mathrm{G}= & \text { Rata-rata laju pertumbuhan sektor } \\
& \text { usaha Indonesia }
\end{aligned}
$$

Apabila nilai DLQ > 1, maka potensi perkembangan sektor usaha di Propinsi Maluku Utara lebih cepat dibandingkan sektor yang sama di Indonesia, dengan kata lain masih dapat diharapkan menjadi sektor basis pada masa mendatang. Namun apabila nilai DLQ $<1$, maka potensi perkembangan sektor usaha di Propinsi Maluku Utara lebih rendah dibandingkan Indonesia secara keseluruhan, dengan kata lain tidak dapat diharapkan menjadi sektor basis di masa yang akan datang.

\subsection{Klasifikasi Sektor Usaha}

Berdasarkan nilai SLQ dan DLQ, dapat ditentukan klasifikasi sektor usaha apakah tergolong Sektor Unggulan, Sektor Prospektif, Sektor Andalan, dan Sektor Tertinggal (lihat Tabel 1).

Tabel 1. Klasifikasi Sektor Berdasarkan Nilai SLQ dan DLQ

\begin{tabular}{ccc}
\hline Kriteria & SLQ $>1$ & SLQ $<1$ \\
\hline$D L Q>1$ & Sektor Unggulan & Sektor Andalan \\
$D L Q<1$ & Sektor & Sektor \\
& Prospektif & Tertinggal \\
\hline
\end{tabular}

Sumber: Santoso, dkk., 2012

Berdasarkan matriks tersebut dapatlah diketahui klasifikasi sektor usaha terdiri atas 4 sektor, yaitu :

a. Sektor Unggulan, syaratnya DLQ $>1$ dan SLQ > 1, merupakan sektor yang pada saat ini merupakan sektor unggulan dan tetap berpotensi unggul pada beberapa tahun ke depan.

b. Sektor Andalan, syaratnya DLQ $>1$ dan SLQ $<1$, merupakan sektor yang pada saat ini belum unggul tapi dalam beberapa waktu ke depan berpotensi unggul.

c. Sektor Prospektif, syaratnya SLQ $>$ dan DLQ $<1$, merupakan sektor yang pada saat ini merupakan sektor unggulan tetapi tidak berpotensi unggul pada beberapa waktu ke depan.

d. Sektor Tertinggal, syaratnya SLQ $<1$ dan DLQ < 1, merupakan sektor yang dinyatakan tidak unggul untuk saat ini dan pada beberapa waktu ke depan pun belum berpotensi untuk menjadi sektor unggulan.

\section{HASIL DAN PEMBAHASAN}

3.1. Analisis Kinerja Sektor Pertanian dan Non Pertanian di Propinsi Maluku Utara

Kinerja sektor pertanian dan non pertanian dapat digolongkan ke dalam sektor basis dan non basis melalui analisis Location Quotient (LQ). Adapun hasil analisis Location Quotient untuk mengidentifikasi kinerja sektor pertanian dan non pertanian di Propinsi Maluku Utara dapat dilihat pada Tabel 2.

Berdasarkan hasil analisis LQ diketahui bahwa sektor yang merupakan sektor basis di Propinsi Maluku Utara adalah sektor pertanian dengan rata-rata nilai LQ sebesar 2.63. Secara khusus sub sektor yang merupakan sektor basis adalah pertanian tanaman pangan dengan ratarata nilai $L Q$ sebesar 1,41 , rata-rata nilai $L Q$ sub sektor perkebunan sebesar 8,74 , rata-rata nilai LQ sub sektor kehutanan sebesar 2,53, dan sub sektor perikanan memiliki rata-rata nilai LQ sebesar 1,99. Sektor non pertanian yakni Perdagangan, Hotel dan Restoran juga merupakan sektor basis dengan nilai rata-rata LQ sebesar 1,55. Bilamana nilai $L Q>1$ berarti bahwa peranan suatu sektor di Propinsi Maluku Utara lebih dominan dibandingkan sektor di tingkat nasional dan sebagai petunjuk bahwa sektor perekonomian merupakan sektor basis di Propinsi Maluku Utara. Sedangkan sektor lainnya memiliki rata-rata nilai $\mathrm{LQ}<1$. Hal ini berarti peranan sektor tersebut lebih kecil di propinsi Maluku Utara dibandingkan peranannya di tingkat nasional berarti sektor tersebut merupakan sektor non basis.

Nilai tersebut telah menunjukkan bahwa sektor pertanian merupakan sektor yang mandiri dan mampu mencukupi kebutuhan wilayah lokal dan surplus produksinya dapat diekspor keluar wilayah. Komoditi utama tanaman pangan adalah padi sawah, padi ladang, jagung, ubi jalar dan ubi kayu. Tanaman pangan produksi padi sawah di 
Propinsi Maluku Utara tahun 2012 sebesar 57.835 ton yang dipanen dari areal seluas 14.597 ha atau rata-rata 3,96 ton per hektar. Sedangkan produksi padi ladang sebesar 8.833 ton dengan luas panen 3.974 ha atau rata-rata produksi 2,23 ton/ha. Produksi jagung pada tahun 2012 sebesar 25.553 ton dengan luas panen 11.074 ha atau rata-rata 2,30 ton/ha. Produksi tanaman lainnya seperti ubi jalar sebesar 34.660 ton dan ubi kayu sebesar 116.515 ton.

Tabel 2. Hasil Analisis Location Quotient Menurut Lapangan Usaha di Propinsi Maluku Utara

\begin{tabular}{|c|c|c|c|c|c|c|c|c|}
\hline No & Lapangan Usaha & 2008 & 2009 & 2010 & 2011 & 2012 & $\begin{array}{l}\text { Rata- } \\
\text { Rata }\end{array}$ & Keterangan \\
\hline 1 & Pertanian & 2,63 & 2,61 & $2 ., 62$ & 2,65 & 2,64 & 2,63 & Basis \\
\hline a & Pertanian Tanaman Pangan & 1,46 & 1,40 & 1,40 & 1,40 & 1,41 & 1,41 & Basis \\
\hline b & Perkebunan & 8,42 & 8,71 & 8,77 & 8,91 & 8,88 & 8,74 & Basis \\
\hline c & Peternakan & 0,78 & 0,75 & 0,74 & 0,74 & 0,72 & 0,75 & Non Basis \\
\hline d & Kehutanan & 2,49 & 2,58 & 2,51 & 2,51 & 2,56 & 2,53 & Basis \\
\hline e & Perikanan & 2,07 & 2,02 & 2,04 & 1,95 & 1,87 & 1,99 & Basis \\
\hline 2 & Pertambangan dan Penggalian & 0,58 & 0,49 & 0,51 & 0,52 & 0,52 & 0,53 & Non Basis \\
\hline 3 & Industri Pengolahan & 0,48 & 0,48 & 0,47 & 0,46 & 0,45 & 0,47 & Non Basis \\
\hline 4 & Listrik, Gas dan Air Bersih & 0,68 & 0,60 & 0,60 & 0,62 & 0,62 & 0,62 & Non Basis \\
\hline 5 & Bangunan & 0,28 & 0,28 & 0,28 & 0,29 & 0,30 & 0,29 & Non Basis \\
\hline 6 & Perdagangan, Hotel dan Restoran & 1,44 & 1,55 & 1,57 & 1,59 & 1,63 & 1,55 & Basis \\
\hline 7 & Pengangkutan dan Komunikasi & 0,99 & 0,92 & 0,86 & 0,83 & 0,80 & 0,88 & Non Basis \\
\hline 8 & Keuangan, Persewaan dan Jasa & 0,37 & 0,38 & 0,38 & 0,38 & 0,38 & 0,38 & Non Basis \\
\hline 9 & Jasa-Jasa & 0,83 & 0,82 & 0,84 & 0,85 & 0,86 & 0,84 & Non Basis \\
\hline
\end{tabular}

Sumber : Data diolah, 2014

Tahun 2012, kawasan hutan dan perairan di Maluku Utara tercatat seluas 2.780.082,74 ha, terdiri dari $583.975,28$ ha hutan lindung, 667.192,65 ha hutan produksi terbatas, $482.284,32$ ha hutan produksi tetap, 567.614,18 ha hutan produksi konversi, 218.557,48 ha taman nasional, suaka alam dan konversi alam, dan sisanya seluas $11.511,93$ ha merupakan perairan. Produksi hasil hutan tahun 2012 hanya menghasilkan kayu bulat $26.931,85 \mathrm{~m}^{3}$. Sub sektor perikanan juga merupakan sektor basis, dimana kondisi geografis Maluku Utara yang dikelilingi laut menjadikan wilayah ini kaya akan produk bahari. Produksi perikanan pada tahun 2012 sebanyak 122.738,17 ton dimana sebanyak $121.427,69$ ton merupakan perikanan laut.

Produk sub sektor perkebunan yang cukup dominan di Maluku Utara adalah tanaman kelapa dan kakao, dengan produksi masing-masing sebesar 260.697 ton dan $\mathbf{1 3 . 1 5 8}$ ton. Peternakan hewan ternak yang terdapat di Maluku Utara pada 2012 adalah sapi potong, kerbau, kuda, kambing dan babi. Sedangkan unggas seperti ayam kampung, ayam petelor, ayam pedaging dan bebek. Jumlah populasi sapi potong dan kerbau masing-masing sebanyak 64.136 dan 240 ekor.

3.2. Analisis Kinerja Sektor Pertanian dan Non Pertanian di Propinsi Maluku Utara pada Masa Mendatang

Kinerja sektor pertanian dan non pertanian di Propinsi Maluku Utara pada masa mendatang apakah akan mengalami peningkatan kinerja, penurunan kinerja ataupun stabil di masa sekarang dan mendatang, akan ditunjukkan oleh hasil analisis DLQ pada Tabel 3.

Hasil analisis Tabel 3 menunjukkan bahwa di masa mendatang beberapa sektor basis seperti sektor pertanian, pertanian tanaman pangan, perkebunan, dan perikanan akan mengalami peningkatan kinerja. Sedangkan sub sektor peternakan awalnya termasuk sektor non basis maka akan mengalami peningkatan menjadi sektor basis di waktu mendatang.

Kondisi ini dimungkinkan karena penjabaran RPJMD Tahun 2009-2013 yakni 
RKPD Provinsi Maluku Utara Tahun 2014, maka kegiatan pembangunan diarahkan pada (Bappeda Propinsi Maluku Utara, 2013) :

1. Peningkatan keragaman sumber bahan pangan, kelembagaan dan budaya lokal;

2. Peningkatan distibusi dan ketersediaan pangan;

3. Menjamin ketersediaan gizi dan pangan bagi masyarakat;

4. Peningkatan keberdayaan dan kemandirian masyarakat;

5. Peningkatan kontribusi sektor pertanian terhadap Produk Domestik Regional Bruto (PDRB);
6. Pengembangan usaha pertanian terpadu (pertanian tanaman pangan, peternakan, perkebunan, perikanan dan kehutanan)

7. Penyusunan Perda sebagai implementasi UU 41/2001 tentang perlindungan lahan pertanian dan peningkatan ketahanan pangan;

8. Peningkatan produksi komoditas hortikultura dan perkebunan;

9. Pengembangan pelabuhan perikanan sebagai akses pengembangan potensi perikanan;

10. Pengembangan sentra-sentra produksi peternakan.

Tabel 3. Hasil Analisis Dynamic Location Quotient Menurut Lapangan Usaha di Propinsi Maluku Utara

\begin{tabular}{llccccccc}
\hline No & \multicolumn{1}{c}{ Lapangan Usaha } & $\mathbf{2 0 1 3}$ & $\mathbf{2 0 1 4}$ & $\mathbf{2 0 1 5}$ & $\mathbf{2 0 1 6}$ & $\mathbf{2 0 1 7}$ & $\begin{array}{c}\text { Rata- } \\
\text { Rata }\end{array}$ & Keterangan \\
\hline 1 & Pertanian & 0,61 & 0,77 & 2,42 & 1,30 & 0,69 & 1,16 & Basis \\
& a. Pertanian Tanaman Pangan & 0,29 & 0,11 & 7,70 & 5,15 & 1,30 & 2,91 & Basis \\
& b. Perkebunan & 1,32 & 14,87 & 1,24 & 0,42 & 0,22 & 3,61 & Basis \\
& c. Peternakan & 2,37 & 0,77 & 1,00 & 0,85 & 0,46 & 1,09 & Basis \\
& d. Kehutanan & $-215,07$ & 1,01 & 0,10 & 2,23 & 41,84 & $-33,98$ & Non Basis \\
& e. Perikanan & 1,31 & 3,64 & 1,42 & 0,34 & 0,43 & 1,43 & Basis \\
2 & Pertambangan dan Penggalian & 55,42 & $-0,38$ & 0,69 & 9,21 & 7,28 & 14,44 & Basis \\
3 & Industri Pengolahan & $-7,46$ & 30,46 & 2,29 & 0,51 & 0,53 & 5,27 & Basis \\
4 & Listrik, Gas dan Air Bersih & 0,14 & 0,04 & 9,16 & 15,03 & 4,29 & 5,73 & Basis \\
5 & Bangunan & 1,12 & 0,75 & 0,73 & 1,38 & 0,98 & 0,99 & Non Basis \\
6 & Perdagangan, Hotel dan Restoran & 0,76 & 455,54 & 0,40 & 0,27 & 0,51 & 91,50 & Basis \\
7 & Pengangkutan dan Komunikasi & 0,51 & 0,48 & 0,88 & 1,93 & 3,23 & 1,41 & Basis \\
8 & Keuangan, Persewaan dan Jasa & 0,45 & 3,15 & 1,72 & 0,85 & 0,59 & 1,35 & Basis \\
9 & Jasa-Jasa & 0,59 & 0,84 & 1,44 & 0,73 & 1,78 & 1,07 & Basis \\
\hline
\end{tabular}

Sumber : Data diolah, 2014

Sektor non pertanian pun menunjukkan peningkatan kinerja sehingga menjadi sektor basis dimasa mendatang, yaitu sektor pertambangan dan penggalian, industri pengolahan, listrik, gas dan air bersih, perdagangan, hotel dan restoran, pengangkutan dan komunikasi, keuangan, persewaan dan jasa, dan sektor jasa-jasa. Sektor non pertanian ini mempunyai laju pertumbuhan sektor terhadap laju pertumbuhan PDRB di Propinsi Maluku Utara lebih cepat, jika dibandingkan laju pertumbuhan sektor tersebut terhadap PDB nasional, hal ini ditunjukkan oleh nilai LQ yang lebih besar dari 1 .

Kontribusi sektor pertambangan non migas terhadap perekonomian Maluku Utara tidak melebihi 5 persen dalam jangka waktu 5 tahun terakhir, namun dapat ditingkatkan melalui peningkatan nilai tambah dengan potensi yang jauh lebih besar. Hal ini dikarenakan adanya batasan minimum pengolahan dan/atau pemurnian komoditas tambang dengan nilai yang jauh lebih besar daripada menjual komoditas tambang dalam bentuk mentah (tanah). Melalui penerapan Peraturan Menteri ini, kontribusi saat ini dapat dijaga meskipun dengan pengurangan produksi pertambangan untuk fokus terhadap kualitas lingkungan di Maluku Utara (Bappeda Propinsi Maluku Utara, 2013).

Sasaran pembangunan di Propinsi Maluku Utara sektor industri pengolahan 
adalah meningkatnya produktivitas usaha perikanan tangkap dan budidaya, meningkatnya diversifikasi produk siap saji untuk pasar dalam dan luar negeri; berkembangnya klaster industri perikanan; berkembangnya penganekaragaman produk kelapa; dan berkembangnya kluster industri kelapa dengan sebagai pusat industri pengolahan.

Arah kebijakan listrik, gas dan air bersih yaitu diantaranya meningkatnya rasio elektrifikasi, yaitu perbandingan antara jumlah rumah tangga yang telah mendapat pelayanan listrik dengan total jumah rumah tangga di suatu daerah. Sedangkan pemerintah daerah pun terus-menerus menggalakan program penyediaan air bersih bagi rumah tangga dalam kehidupan sehari-hari terutama keperluan minum.

Sasaran pembangunan di Propinsi Maluku Utara sektor pengangkutan dan komunikasi diantaranya adalah meningkatnya kapasitas dan kualitas pelayanan prasarana jalan dan dan jembatan kawasan-kawasan pusat pertumbuhan ekonomi serta meningkatkan aksesibilitas kawasan melalui dukungan pelayanan prasarana transportasi darat, laut dan udara. Saat ini sarana angkutan penyeberangan antar pulau dilayani oleh speedboat, kapal angkutan laut lainnya. Khusus kapal feri telah beroperasi diantaranya: Bastiong, Sidangoli, Rum, Dowora, Sofifi, Subaim, Tobelo, Daruba, Babang, Obi, Falabisahaya dan Sanana. Sedangkan pelayaran PELNI melayani angkutan laut lintas provinsi yang menghubungkan Maluku Utara, Maluku, Papua, Sulawesi, Kalimantan, dan Jawa. Pembangunan sektor perhubungan tentunya akan mendukung sektor perdagangan. Dimana arah kebijakan pembangunan tahun 2014 adalah meningkatnya pangsa pasar armada pelayaran baik untuk angkutan laut dalam negeri maupun ekspor-impor.

Jasa perbankan dari tahun ke tahun menunjukkan kecenderungan meningkat seiring dengan semakin banyaknya kegiatan perekonomian masyarakat yang membutuhkan jasa ini. Jumlah bank di Maluku Utara pada tahun 2011 tercatat 68 bank dan 820 koperasi yang tersebar di berbagai daerah di Maluku Utara.
Sedangkan sektor kehutanan dan bangunan memiliki laju pertumbuhan sektor terhadap laju pertumbuhan PDRB Propinsi Maluku Utara lebih rendah dibandingkan laju pertumbuhan sektor tersebut terhadap PDB nasional. Dengan kata lain, kedua sektor ini merupakan sektor yang tidak memiliki potensi perkembangan lebih cepat dibandingkan dengan perkembangan di tingkat nasional. Menurut BPS (2013), nilai tambah sub sektor kehutanan mengalami penurunan 2 persen dibandingkan tahun 2012. Pertumbuhan sub sektor ini mengalami penurunan disebabkan penurunan aktivitas produksi sektor kehutanan di beberapa kabupaten di Maluku Utara. Peraturan dan izin yang semakin ketat terkait dengan pemotongan kayu hasil hutan diduga berpengaruh terhadap penurunan produksi kehutanan di Maluku Utara.

\subsection{Klasifikasi Sektor Ekonomi di Propinsi Maluku Utara \\ Hasil klasifikasi pada Tabel 4} menunjukkan bahwa sektor pertanian secara umum masih merupakan sektor unggulan di Propinsi Maluku Utara. Sub sektor pertanian yang unggul yaitu pertanian tanaman pangan, perkebunan, dan perikanan. Sektor lainnya adalah sektor perdagangan, hotel dan restoran. Sektor-sektor ini saat ini merupakan sektor unggulan dan tetap berpotensi unggul untuk beberapa tahun ke depan.

Sektor andalan di Propinsi Maluku Utara adalah peternakan, pertambangan dan penggalian, industri pengolahan, listrik, gas dan air bersih, pengangkutan dan komunikasi, keuangan, persewaan dan jasa, serta sektor jasa-jasa. Sektor-sektor ini pada saat ini belum unggul tapi dalam beberapa waktu ke depan berpotensi unggul.

Sektor prospektif adalah kehutanan, dimana pada saat ini merupakan sektor unggulan tetapi tidak berpotensi unggul pada beberapa waktu ke depan. Berikutnya adalah sektor tertinggal adalah sektor bangunan, merupakan sektor yang tidak unggul untuk saat ini dan pada beberapa waktu ke depan pun belum berpotensi untuk menjadi sektor unggulan. 
Tabel 4. Klasifikasi Sektor Berdasarkan Nilai SLQ dan DLQ

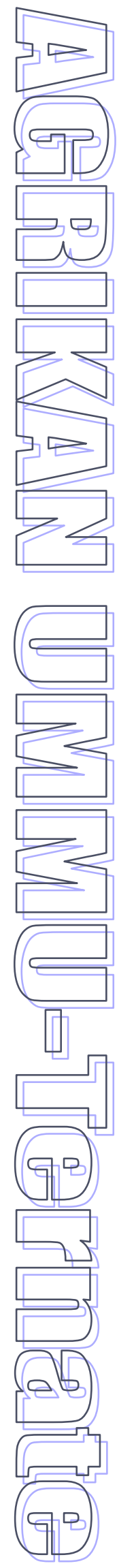

\begin{tabular}{|c|c|c|}
\hline Kriteria & SLQ $>1$ & SLQ $<1$ \\
\hline \multirow[t]{8}{*}{$\mathrm{DLQ}>1$} & Sektor Unggulan & Sektor Andalan \\
\hline & Pertanian & Peternakan \\
\hline & Pertanian tanaman pangan & Pertambangan dan Penggalian \\
\hline & Perkebunan & Industri Pengolahan \\
\hline & Perikanan & Listrik, Gas dan Air Bersih \\
\hline & Perdagangan, hotel dan restoran & Pengangkutan dan komunikasi \\
\hline & & Keuangan, Persewaan dan jasa \\
\hline & & Jasa-jasa \\
\hline$D L Q<1$ & $\begin{array}{c}\text { Sektor Prospektif } \\
\text { Kehutanan }\end{array}$ & $\begin{array}{c}\text { Sektor Tertinggal : } \\
\text { Banqunan }\end{array}$ \\
\hline
\end{tabular}

\section{PENUTUP}

\subsection{Kesimpulan}

Berdasarkan hasil penelitian maka disimpulkan hal-hal berikut :

1. Analisis LQ menunjukkan bahwa sektor pertanian secara umum termasuk sektor basis di Propinsi Maluku Utara, dengan sub sektornya yaitu pertanian tanaman pangan, perkebunan, kehutanan dan perikanan. Sektor pertanian lainnya yaitu peternakan termasuk sektor non basis. Sektor non pertanian yang merupakan sektor basis yaitu perdagangan, hotel dan restoran.

2. Analisis DLQ menunjukkan bahwa di masa mendatang beberapa sektor basis seperti sektor pertanian, pertanian tanaman pangan, perkebunan, dan perikanan akan mengalami peningkatan kinerja. Sedangkan sub sektor peternakan awalnya termasuk sektor non basis maka akan mengalami peningkatan menjadi sektor basis di waktu mendatang. Sektor non pertanian pun menunjukkan peningkatan kinerja sehingga menjadi sektor basis dimasa mendatang, yaitu sektor pertambangan dan penggalian, industri pengolahan, listrik, gas dan air bersih, perdagangan, hotel dan restoran, pengangkutan dan komunikasi, keuangan, persewaan dan jasa, dan sektor jasa-jasa.

3. Klasifikasi sektor di Propinsi Maluku Utara berdasarkan nilai LQ dan DLQ yaitu :

- Sektor unggulan: sektor pertanian, pertanian tanaman pangan, perkebunan, dan perikanan; serta sektor perdagangan, hotel dan restoran.

- Sektor andalan: peternakan, sektor pertambangan dan penggalian, industri pengolahan, listrik, gas dan air bersih, pengangkutan dan komunikasi, keuangan, persewaan dan jasa,serta sektor jasa-jasa.

- Sektor prospektif: kehutanan.

- Sektor tertinggal: bangunan.

\subsection{Saran}

Berdasarkan hasil penelitian dapat disarankan hal-hal sebagai berikut :

1. Pemerintah Propinsi Maluku Utara dapat memprioritas pengembangan sektor basis dan unggul melalui kebijakan program yang mendorong percepatan pertumbuhan sektor pertanian dan non pertanian khususnya perdagangan, hotel dan restoran.

2. Kebijakan juga diarahkan bagi pengembangan sektor non basis dan andalan, yaitu peternakan, sektor pertambangan dan penggalian, industri pengolahan, listrik, gas dan air bersih, pengangkutan dan komunikasi, keuangan, persewaan dan jasa, serta sektor jasa-jasa; sehingga dapat meningkat dan diwaktu mendatang dapat mencukupi kebutuhan didalam maupun diluar Propinsi Maluku Utara.

\section{DAFTAR PUSTAKA}

Adisasmita, R., 2005. Dasar-Dasar Ekonomi Wilayah, Graha Ilmu, Yogyakarta.

Arsyad, L., 1999. Pengantar Perencanaan dan Pembangunan Ekonomi Daerah, BPFE, Yogyakarta.

Badan Pusat Statistik Provinsi Maluku Utara, 2008-2013. Maluku Utara dalam Angka 2008-2013,

Ternate. 
Badan Pusat Statistik, 2008-2012. Statistik Indonesia 2008-2012, Jakarta.

Badan Pusat Statistik, 2013. Statistik Indonesia 2013, www.bps.go.id.

BPS Provinsi Maluku Utara, 2014. Produk Domestik Regional Bruto Menurut Lapangan Usaha Provinsi Maluku Utara 2013. http://malut.bps.go.id/publikasi /flipbook/ 2014/ pdrb_lap/index.html

Bappeda Provinsi Maluku Utara, 2013. Rencana Kerja Pemerintah Daerah (RKPD) Provinsi Maluku Utara Tahun 2014, Sofifi.

Budiharsono, S., 2005. Teknis Analisis Pembangunan Wilayah Pesisir dan Lautan, Pradnya Paramita, Jakarta.

Hendayana, R., 2003. Aplikasi Metode Location Quotient (LQ) dalam Penentuan Komoditas Unggulan Nasional, Informatika Pertanian 12 (1) : 658-675.

Saharuddin, S., 2006. Analisis Ekonomi Regional Sulawesi Selatan, Jurnal Analisis, Volume 3 (1), Maret 2006: 11 - 24.

Santoso, E. B., dkk., 2012. Analisis Keterkaitan Wilayah Secara Sektoral Kawasan GKS Plus terhadap Jawa Timur: Implikasinya terhadap Pengembangan Perkotaan, Seminar Nasional CITIES 2012, http://personal.its.ac.id/files/pub/4948-eko_budi-urplanPaper\%20Cities2012_Analisis\%20Keterkaitan\%20Wilayah\%20secara\% 20Sektoral\%20Ditinjau\%20dari\%20Sektor\%20Unggulan\%20Wilayah\%20di\%20Kawasan \%20GKS\%20Plus.pdf

Setiono, D. NS., 2011. Ekonomi Pengembangan Wilayah: Teori dan Analisis, FE UI, Jakarta Sjafrizal, 2008. Ekonomi Regional, Teori dan Aplikasi, Baduose Media, Cetakan Pertama, Padang.

Widodo, T., 2006. Perencanaan Pembangunan: Aplikasi Komputer (Era Otonomi Daerah), UPP STIM YKPN, Yogyakarta. 